\title{
THE GARDEN CITY CONCEPT: \\ FROM THEORY TO IMPLEMENTATION \\ CASE STUDY: PROFESSORS' COLONY IN BELGRADE
}

\author{
A B S T R A C T
}

This paper presents a part of the town-planning history of the capital of Serbia - Belgrade. The subject of the research* is the analysis of the application of Ebenezer Howard's Garden City Concept in Belgrade in the third decade of the twentieth century. Special attention was devoted to the urban discourse in the first decades of the last century. The narrower referential framework of this work focuses on investigating the urban growth and development of Belgrade in the first decades of the twentieth century. In Belgrade there are dwelling quarters that were created in the period between the World Wars as a direct consequence of the implementation of the Garden City Concept. One of the basic thesis of this work elaborates the modes of the genesis of one of them - the Professors' Colony, and seeks to distinguish specific applications of the Garden City Concept in relation to Belgrade's specific social conditions. 


\section{INTRODUCTION _ THEORETICAL FRAMEWORK}

"Palatial edifices and fearful slums are the strange, complementary features of modern cities." 1

The fusion of diverse technological, economic and social conditions at the end of the eighteenth century contributed largely to speeding up industrialization in Western Europe, particularly in Great Britain, which, by the middle of the nineteenth century, became the leading industrial country in the world. In the big cities of the United Kingdom, the Industrial Revolution simultaneously brought about the concentration of both the power and the misery, which was most obvious in the places where the weakest participants in the production chain lived - the laborers' suburbs of a metropolis. Throughout the nineteenth century, these suburbs managed to survive among constantly expanding centers, huge traffic junctions, as well as, within already defined, urban industrial zones. The situation was similar at the beginning of the twentieth century: the lack of space, overpopulation and general dehumanization of the living conditions of the majority of people - those still remained the main problems of the big cities. These phenomena and the complementary opposites that coexisted in the big cities were also noticed by Ebenezer Howard (18501928), who tried to eliminate or at least reduce them - by creating the theoretical concept which he published as two editions of a book: To-Morrow: a Peaceful Path to Real Reform ${ }^{2}$ and Garden Cities of To-Morrow ${ }^{3}$. The first lecture on the Garden City Concept was already given by Howard in London, almost ten years earlier — in February $1893 .{ }^{4}$

The initial stages for creating a modern legislation on urban planning and social welfare were established in Great Britain. The first attempts at creating the legal basis for dealing with the issues of miserable housing in the poor suburbs of the industrial centers in Great Britain have been made since the first half of the nineteenth century; however, the local community councils, whose assignment was to monitor the hygienic conditions in the suburbs, had very little authority to influence the existing conditions back then. This applied especially to London, the birthplace of Ebenezer Howard, where this problem was the most noticeable, additionally worsened by the poverty of the labor class, the epidemics of fatal infective diseases, which all led to constant civic unrest. Those were, in short, the conditions in which Howard's concept was created. According to the definition given by Garden Cities \& Town Planning Association in 19195:

"A Garden City is a Town designed for healthy living and industry; of a size that makes possible a full measure of social life, but not larger; 
surrounded by a rural belt; the whole of the land being in public ownership or held in trust for the community."

According to Howard, the ideal type of a settlement would be the one that has all the advantages of both the urban and the rural lifestyles and that way, naturally, would avoid all the adverse qualities that make everyday life more difficult. Howard hoped that a town built according to the Garden City Concept would be "the Third Magnet" that would attract the most of the unhappy inhabitants of the British suffocating industrial cities, and thus resolve one of the biggest national problems of the time. ${ }^{6}$ (Fig. 1, Diagrams 1 and 3)

Founding of the Garden City Association, 1899, can be considered as the first step in the application of the Garden City theory. In the year 1902, The Garden City Pioneer Company was established, which, soon after, acquired the capital needed for creation of the first Garden City by selling the shares. The place chosen for the First Garden City in the world was located $50 \mathrm{~km}$ North-East of London, on the way to Cambridge, in Hertfordshire. After the formal opening ceremony of the construction site on October 9th 1903, a long journey of creating Letchworth, The World's First Garden City, begun. The Garden City movement contributed greatly to town planning in Great Britain and, in the world as well. ${ }^{7}$ (Fig. 2, Dwelling Quarters, Letchworth)

\section{A GARDEN CITY IN BELGRADE}

The first application of the Garden City Concept in Belgrade happened in the period between the World Wars; however, the term "Garden City" was intrinsically and in the terms of terminology present in the urban discourse of Belgrade at the turn of the centuries.
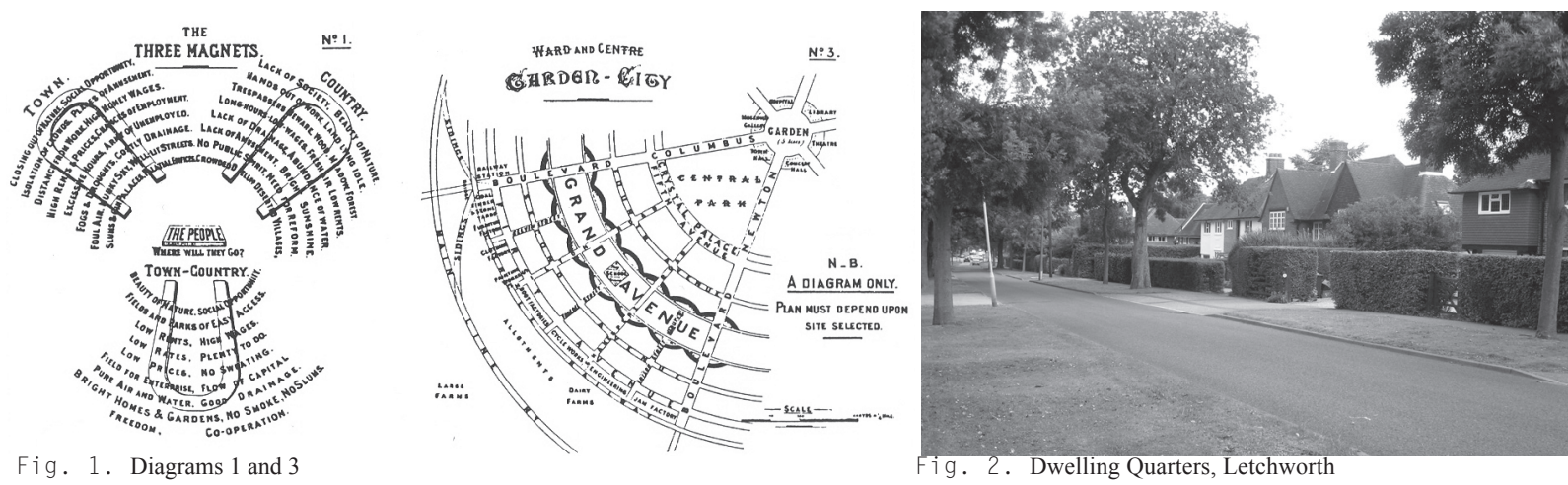
At the end of the nineteenth century, the dominant historical events in Serbia were related to the main characteristics of the century - the founding of the national state. The metamorphosis of Belgrade's urban structure and its visual transformation followed with dedication the course of historical events. The verses on the sixteenth century engraving by the German artist Daniel Meissner showing "the allegory of the fall of Belgrade,"describe the main course of its history: "A lad, an adder and a boar/ Caught together in a death struggle/ Boar by a stab, lad by the venom/ And adder crushed by the hoof." " Belgrade became the capital of Serbia in 1841. In 1874, it had a population of 27.000 inhabitants and covered the area of 580ha. Only a quarter of a century later, as many as 64.000 people lived there. The number of people living in Belgrade in 1910 was around 90.000 with the city spreading over 1.090 ha. The city plumbing system started functioning in 1892, the electric lights were installed in 1893 and the works on modern sewage system began in 1905. The regulation of Belgrade, by the Decree of King Aleksandar Obrenović , was transferred from the Ministry of Building to the Municipality of Belgrade, in 1892.

\section{FORMING THE DISCOURSE}

By the end of the nineteenth century, in 1894, the Sanitary Department with the Municipality of the City of Belgrade was founded. Also, in the last decade of the nineteenth century, for the first time a magazine of the Society of Serbian Engineers and Architects — Serbian Technical Paper [Српски технички лист], was published. At the turn of the centuries, the awareness of the necessity of establishing housing hygiene standards in addition to cooperation of the engineering and health professions in this area, continually grew in the Serbian professional society in Belgrade, and the texts addressing that subject started being published in this magazine. The fact that the situation in this field was worsening with each year resulted in even more frequent public presentations of the architects, engineers, municipal officers, doctors, intended to introduce the negative consequences the bad housing c onditions can cause, and presenting the bad hygienic conditions in the residential communities of Belgrade, as well as defining and establishing the standards of hygienically correct dwelling. In the article "The Regulation of Belgrade", in Serbian Technical Paper, Jefta Stefanović speaks in favor of the new regulation plan of Belgrade:9 "Belgrade is spreading. For the population increase of 80,000 the town stretched on the area that could easily accommodate 400,000 people; and waterworks, paving and sewage system is needed. [...] I think that a competition calling for submission of a new regulation plan of Belgrade design should be announced, the one with big rewards so that the world- 
known experts could be involved." Serbian Technical Paper paid full attention to the information on the international innovations in architectural and urban design theory and practice. Thus, in one of the issues, an information on newly published books appeared and as a part of it a brief report on the German translation of Raymond Unwin's Town Planning in Practice: An Introduction to the Art of Designing Cities and Suburbs (1909). ${ }^{10}$ During the last peaceful months of 1914, in one of the texts explaining his design of the Theater Square (Republic Square nowadays) in Belgrade, an architect, Stanojlo Babić, refers to Unwin, quoting a fragment from his book [the article "Pozorišni trg" (Theater Square)]. This quote explains the urban design credo of Unwin, being one of the first interpreters of the Garden City Concept, and his essential approach to town-planning: ${ }^{11}$

„The Englishman Raymond Unwin [Unwin Grundlagen des Städtebaues, Berlin, 1910, p. 77] says 'We must admit that we, the Englishmen, are but beginners in this art of town planning and I sense it well that we still cannot try to definitely position the exact borderline between the method of regular geometrical shapes and the working technique by the principles of the greatest freedom and usage of free shapes and that it is, in this moment, most inconvenient to wish for the town planner not to show certain devotion to one or the other way of building but to properly evaluate the importance and value of both and to make, at a certain moment, the correct judgment that must be based on the thorough evaluation of these arguments that speak in favor of one or the other principle."”

When we speak precisely of the emergence of the term "Garden City" we find it slightly altered and seemingly just mentioned, in the text by Dimitrije T. Leko (1863-1914), published also in Serbian Technical Paper, in 1908, under the title: "Thoughts on Possibility of Application of the Serbian style": ${ }^{2}$

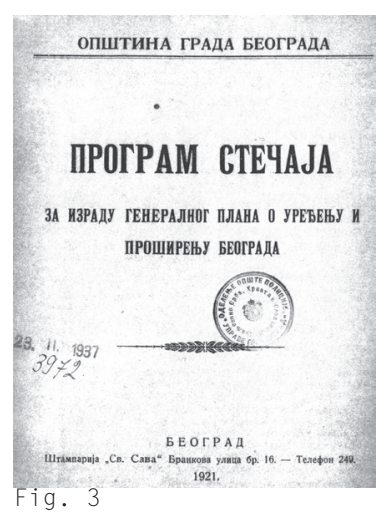


"In big cultural cities, a natural main course by which people build in order to shelter themselves from the street traffic noise and polluted air can be clearly seen. In London, its sheltered squares in the middle of big blocks and big parks in the middle of the city are the real proof that this main course exists. Furthermore, the whole towns in gardens (Gartenstädte) or the designed Wald und Wiesen-Ring around Vienna, etc, it all comes closer and closer to oriental teferič and bulbuder, where a man would once again feel as a man and not a small rivet in a huge deafening machine. [...] even here, healthier ideas gradually infiltrate the common thinking, and this can bring some comfort. Besides that, as we have seen above, the city within the garden and oriental type of buildings are the most modern (and the most natural) aspirations of the cultural world and that is why the hope that it won't take long before we come to that cognition is justified, since we are not that fortunate to precede the world with the example created from our directly inherited surroundings."

When it concerns promotion of the Garden City idea in Serbia, there were several important figures in the period between the two World Wars:

First of all, it was Jan Dubový (1892-1969), a Czech architect working at the Municipality of Belgrade. He gave a detailed preview of the Garden City Concept to the Serbian and Yugoslav professional public. ${ }^{13} \mathrm{He}$ was the most informed on the Garden City Concept, its history, theory and practice. His texts from 1925, address the theoretical presumptions of the Garden City and its practical realizations. ${ }^{14}$ Branko Maksimović was an architect and the author of the book Problems of Urbanism, ${ }^{15}$ from 1932, knowing well the Garden City Cocept and, also, its German
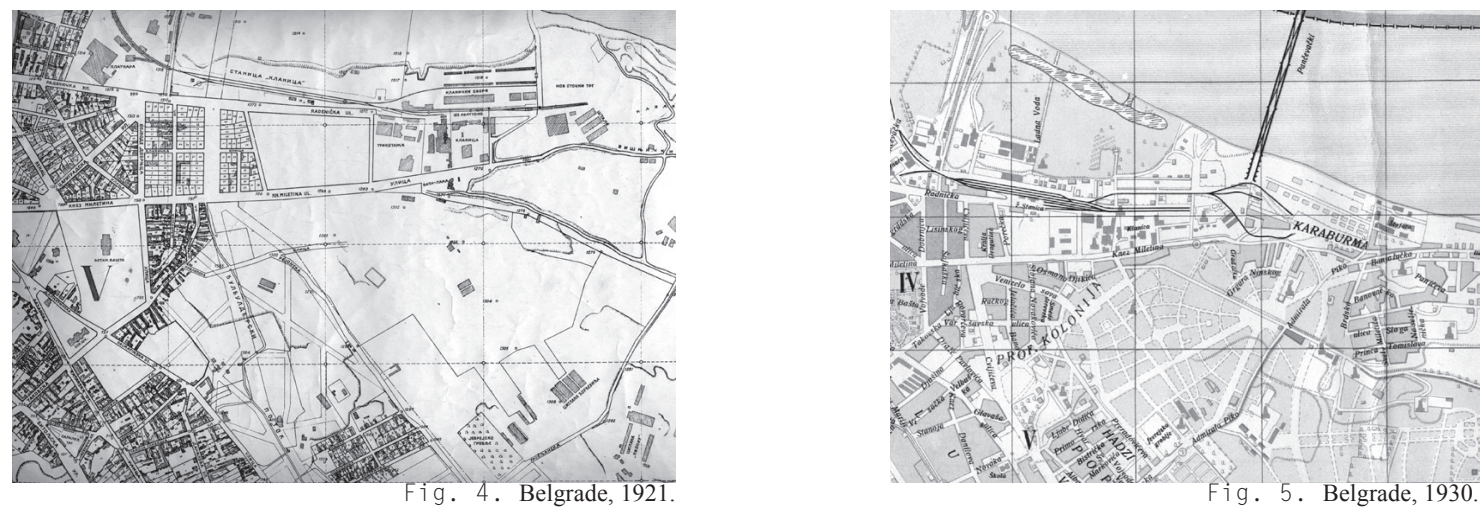
interpretations, and he translated his experience into the model of the possible local implementation. Slobodan Ž. Vidaković was a sociologist, a writer and the editor of the magazine Belgrade Municipal Paper. ${ }^{16}$ At that time this paper published numerous articles that essentially dealt with the Garden City Concept, and also proved the excellent knowledge and understanding their authors had. Slobodan Vidaković presented in his texts the sociological aspect of the Garden City. (Fig. 3)

After the end of the First World War Belgrade faced the never before experienced problem of lack of living space. Since the beginning of 1919, the Commission for Economic Renewal of Belgrade, through buildings renovation, supply with the construction material and loans granting for dwelling buildings construction, has tried to minimize the problem that, in the following months, led to workers' protests. The situation of civic unrests in Belgrade was similar to the events in other European countries where post-war anger was also heating up. A design competition program for a new General Plan of Belgrade was announced in 1921. Although the Program ${ }^{17}$ proposed forming of planned dwelling communities, as it said, "in the spirit of contemporary views on founding the garden settlements outside the city area", around twenty new communities emerged during this period, but most of them were illegal settlements, with very bad hygiene conditions.

\section{THE PROFESSORS' COLONY}

The Professors' Colony in Belgrade has been formed since 1926. In the first phase of its construction and development, 1926-27, it represented especially one of the aspects of implementing European concepts (like the Garden City Concept was). Unlike the Kotež Neimar neighborhood, in 1924, which was formed in line with the formal characteristics of a Garden Suburb, the Colony was, in its nucleus, the joint action of the group of citizens with similar professional and social provenance, intended to provide them with housing. ${ }^{18}$ (Fig. 4, Belgrade, 1921) (Fig. 5, Belgrade, 1930)

The idea of forming the residential colonies in Belgrade certainly came directly from the General Plan of Belgrade postulates (1923) that initially originated in the Program for the Plan design competition as a result of the already publicly announced aspirations:

"Alignment and regulation of the suburbs is left to the planner's free will, though his attention should be drawn to Belgrade - Avala, Belgrade Rakovica direction for positioning the colonies (the clerks', the railway 
workers', the sailors' etc.) the ideas and desires of the creation of which emerged even before the First World War, as well as to BelgradeCukarica direction and finally downwards to the Danube, where development of the industrial plants with high chimneys and greater working capacity is planned." 19

Following completion of the General Plan of Belgrade in July 1923, the Municipal Commission publicized the Report,$^{20}$ in which the division of the city in several zones was proposed, "in relation to the type of building and settlement density". The expansion limits for each zone and minimal housing parcel size were established, and the plan of use for public building area, public spaces and green spaces was provided and explained, as well as the description of the general characteristics of the zones. The location, on which the Professors' Colony was built, nowadays bordered by Cvijićeva Street, Bulevar Despota Stefana, Mitropolita Petra and Zdravka Čelara streets, was within the second zone, in the "medium density settlement" and on the outskirts of the "dense settlement". In that settlement the new homesteads-parcels could not be smaller than $500 \mathrm{sq} \mathrm{m}$. Following this introduction, the spaces within the second zone, planned for squares, markets, parks and the position of the future workers' settlement were listed. Though it was stated in the text that the second zone contained areas with two different housing densities, they were not defined as the sub-zones nor was the difference between the two precisely articulated. Except for the new buildings' number of floors, the allowed housing density was not imposed, nor were many other specifications that were still to be defined. The General Plan was to give the main guidelines to Belgrade development that would improve street traffic functioning, prevent the chaotic housing building and enable inclusion of green and leisure spaces in the urban tissue and forming of the protective green belt. Soon, the main postulates of the Plan were compromised, so it is important to notice and study every experience that differs from the general course, the creation of the Professors' Colony included. Almost six decades after the idea had been formed and the building of the colony had begun, Branko Maksimović wrote about it in 1983:

"With the building of the standardized houses in the new settlements, according to the General Plan, the housing building started having a more organized, social spirit in the twenties. The first serious step was taken when the Association of the University Professors created the 'Professors' Colony', on the land where vegetable gardens and brickyards used to be, [...] following the example of the foreign 'garden cities'."21 
Many of the experts that were in any sense involved in the urban development of Belgrade at the time the Colony was formed, were also connected to the Garden City Concept, as the people who promoted it. Already mentioned, Jan Dubový, was in charge of the City General Plan development with the Belgrade Municipality at the same time as the Professors' Colony plan was created. Đorđe Kovaljevski, an engineer and head of the Municipal Commission's Bureau that had created Belgrade General Plan in 1923, also, by the end of the twenties, made the plan of parcels for the Clerk's Colony in Voždovac, which, again, according to Jan Dubový's idea, was developed as the application of the Garden City Concept. This quarter should also be distinguished, out of the mass of illegal settlements created in Belgrade between the Wars. Finally, the architect and urban designer Mihailo Radovanović (1899-1975), the author of the book Introduction to Town-Planning, ${ }^{22}$ the creator of the General Plan for Kragujevac in 1931, and, later on, its quarter, the New Colony, took part as one of the associates in designing the plan for the Professors' Colony. Their work was coordinated by the architect, Svetozar Jovanović (1892-1971), professor at the Technical Faculty, who took a part in the Professors' Colony creation from its very beginning. When the settlement was built, he became one of its inhabitants. (Fig. 6, The Professors' Colony)

The first initiative to establish this settlement came with the teachers becoming organized who wanted to solve their housing issues and formed the Association of the University Professors in 1926. The first goals of this organization were:

- to secure the funds for land acquisition and housing construction;

- foundation of the Technical Bureau that prepared the quarter plan and house designs;

- organization of the construction of the buildings and to providing communal facilities in the settlement.

Based on the data contained in the texts on the Professors' Colony, we can create more precise chronology of the events related to its creation and development in 1926-27:

- The idea to establish the university professors' settlement came from Vladimir K. Petković, who at that time (beginning of the 1926) was the Dean of the Faculty of Philosophy, University of Belgrade.

- Organizing the teachers in the endeavor to solve their housing issues, began, as mentioned, with founding of The Association of the University Professors in mid March, 1926.

- The funds required for the land purchase and settlement construction were provided by taking the loan from the National Mortgage Bank. 
- After the loan had been approved, or perhaps, more likely the arrangement with the Mortgage Bank made, forming of the Technical Bureau, consisting of the University teachers, began.

- The Technical Bureau Board, which selected the site for the university teachers' settlement, was formed.

- After the site had been selected, the Technical Bureau undertook "planning and sketching the land" and right after that the plan of the quarter and building designs were made.

- After the site had been divided into parcels and individual residential building plans had been completed, on August $3^{\text {rd }} 1926$, the construction of the Professors' Colony, outside the city building region of the time, started.

- In September 1926, about four hundred workers were engaged in the construction of approximately forty residential buildings.

- It was planned to construct forty-seven buildings, thirty-four of which were to be two-storey buildings and thirteen ground level buildings.

- The first phase of the Colony construction was completed in the first half of 1927.

- The first house in Professors' Colony became occupied in the first days of 1927.

- Simultaneous to this process, construction of the infrastructure systems took place.

- By the end of 1927, the Belgrade Municipality Board gave permission to an individual entrepreneur to open a bus-line on the route: Railway Station_Nemanjina Street - Kneza Miloša Street - Takovska Street Botanical Garden - the Professors' Colony and vice-versa.

- By July 1929, Professors' Colony became a part of the area with completely built sewage network of Belgrade.

Besides the intention to accomplish certain urban design tendencies, the financial power of the investor affected the size of the house plots and, thus, the appearance of the buildings constructed there. Owing to the professional skills of settlement's designer, at least in the beginning phase that we speak of, the optimal quality of the residential buildings, and the surrounding spaces as well, was accomplished. In the beggining of the Professors' Colony concept, primarily, there existed the wish to solve the housing issues of the certain group. The fulfillment of that desire was the result of the application of a settlement concept already proposed by the General Plan. The integration of the two, sometimes even opposed tendencies, that represent the Reality and the Idea, provided an excellent result in the Professors' Colony. (Fig. 7, Fig. 8) 
This part of the text begins with the words of the scientist, Milutin Milanković, on his own house in the Professors' Colony, that he himself designed: ${ }^{23}$

"I decided of my own free will, and bearing in mind all my needs, to personally create the plan for my house using the knowledge I gained at the Viennese Technique. [...] My house is arranged so that it suits best the needs of my family and my scientific work. It has a nice terrace and a large tree-shaded garden that borders the six neighboring ones forming a spacious green complex, a reservoir of fresh air. The thick walls of my house, its shady terrace and those gardens enable me to stay and effortlessly work even during the hottest months of the year."

Same as Milanković, the other inhabitants found peace and tranquility in the Professors' Colony. There, the science papers were written, lectures prepared and the first ideas on organizing the institutes, founding archives, libraries, magazines and new university departments were born. If we pay attention to this settlement's first inhabitants' persona, we can find the plurality of interest as one of their distinguishing features. Milutin Milanković, for instance, besides his scientific and lecturing work, was enrolled in civil engineering (which he was educated for in Vienna) and was, in nineteen-twenties, engaged by the Air Force Command of the Kingdom of the Serbs, the Croats and the Slovenes. Milanković's engagement implied the responsibility for accuracy of the largest of buildings' (airport hangars and workshops) plans and construction calculations, as well as the supervision of its construction. Miroslava Dimić writes about the pioneers of the Colony: ${ }^{24}$

"[A]ll the founders of the Professors' Colony were invited for their quality and knowledge to Belgrade University, so that they could pass their knowledge to students and raise the academic class in Serbia. Therefore, it is not strange that there were 23 Philosophy Doctors and 15 members of the Academy of Science amongst them. Each one of them was the authority in his field, and all of them contributed to bringing the Serbian science to the highest level."
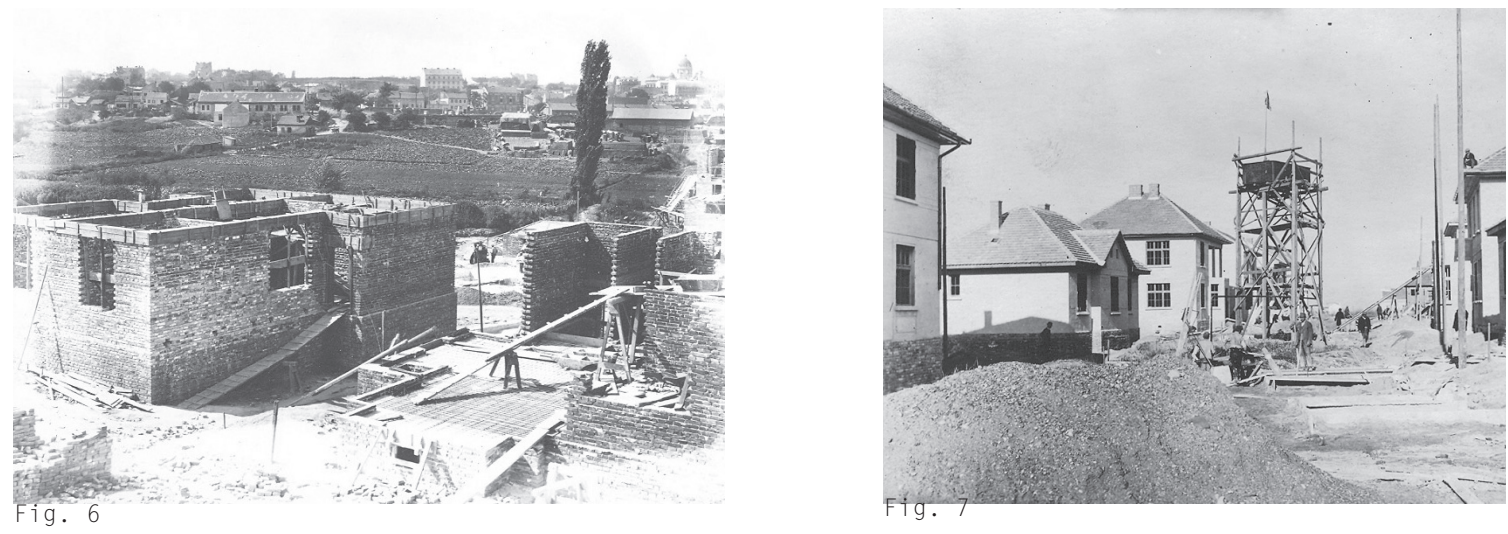


\section{FINAL REMARKS}

If we tried to compare the basic characteristics of a Garden City, the way Howard thought of it in his theory, to its realizations, then even Letchworth, in the initial phase of its forming, would not satisfy the basic criteria that qualify it as the settlement of this type. However, speaking of the First garden city in the world, one could say that Letchworth came to its first centennial, 2003, as not completely but almost realized concept of Ebenezer Howard.

We can say that Howard's idea of "One Hundred Garden Cities After the War" was materialized in the housing construction in Great Britain between two World Wars, that had, like British New Towns after the Second World War, its own line of development. Those were not the settlements that had all the features of a Garden City, as defined by the Garden Cities \& Town Planning Association in 1919. It is also interesting to analyze the application of the Garden City Concept outside Great Britain. The image becomes more intense with the inclusion of the local influence on the imported concept. Diversity in the application of the Garden City abroad depended on the political, economic and cultural level of development of the country as well as on the social/ historical moment it was in.

Though, in a cooperative action, a group of people, led by a shared goal, bought the land for Professors' Colony outside the city building region of the time, this site "got closer" to city center making the Professors' Colony a kind of a Garden Suburb. We can say that, though there were some occurrences of the scheming practice in building between the Wars, Professors' Colony essentially managed to, somehow, maintain the innocence of the original concept, similarly to, after Letchworth the first realization of the Garden City Concept in England, Garden Suburb Hempstead. Henrietta Barnett (1851-1936), its founder, planned for this part of London to be an all-classes-suburb making it, as it was mentioned, on the social level even closer to Howard's concept than Letchworth. Not even
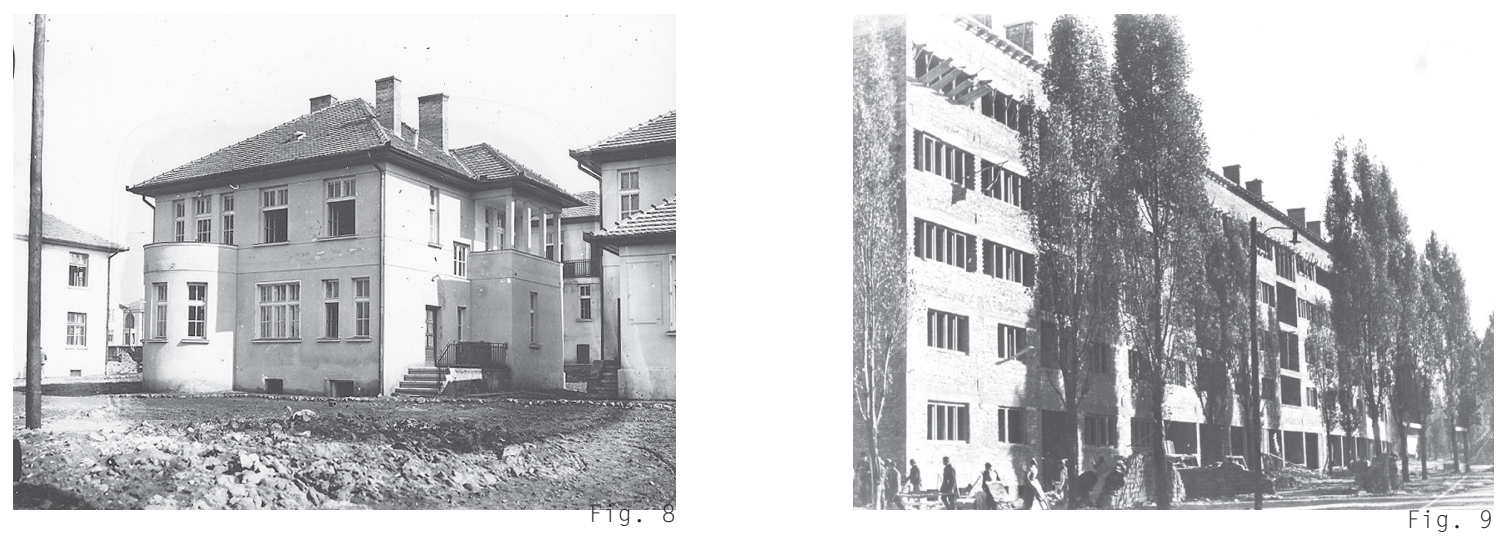
the idea of this social reformer could evade the series of events that the laws of reality had set upon each of these settlements, so the Garden Suburb Hempstead, instead of becoming an all-classes-neighborhood, became a wealthy Londoners' community.

\section{Professors' Colony: Epilogue}

Bratislav Stojanović, an architect and town-planner, wrote about the post-war situation and constructions in Belgrade: 25

"Like the rest of the country, Belgrade was heavily and awfully wounded, destroyed, plunged, with the decreased population. In 1941, it was brutally damaged for the $39^{\text {th }}$ time in its history. [...] Like the rest of the country, Belgrade is in the uplift of the renewal. There are efforts to begin with the planned building as soon as possible. [...] So, in the period from liberation until now [1954], the building of Belgrade wasdone according to the basic presumptions for the General Plan before the Plan itself was made - after that, according to the plan itself."

In our social conditions at the time, almost identically to the Soviet Union's experience, it happened that the Garden City Model, was rejected by the majority of professionals as being a bourgeois concept that encourages individualism. Instead, the collective housing became the model for the future development. However, speaking of Professors' Colony, with the building of collective housing buildings in Cvijićeva Street known as "The Workers' Pavilions" in 1947-1948 ${ }^{26}$ it came to the completion ${ }^{27}$ of the Colony and it became a real all-class-suburb:

"[T]his group of buildings [the Workers' Pavilions] testifies authentically of its time, it illustrates the relationship to space that would become a cliché for many following years and decades, but also a new orientation of the society, directed towards the solution to the problem of a community where an individual and even separate parcel and house could not have been an appropriate model.” (Fig. 9, The Workers' Pavilions)

One of the main features of Howard's theoretical concept implies the existence of the protective green belt around the Garden City. Hempstead and Welwyn, as the early realizations of the garden suburb and Garden City, have, partially, a built barrier with gates to the outer world.

The Workers' Pavilions in the Professors' Colony represented a kind of the built boundary to the community. Not a fortified wall, but a structure that lets 
you enter the neighborhood while preserving the individual concept of the Colony, which continues until this day. Besides the fact that it is edged by the city roads of high intensity, the existence of these residential buildings surely contributed to preservation of the individuality of the urban structure of the Colony until today, though there were attempts, some even realized, to disturb it. In time, the Professors' Colony became a neighborhood compact in its diversity. Likewise, it is diverse in its compactness.

One could say that this quarter is unique amongst Belgrade districts for the integrity of its character. 1902, 1946], p. 47 1898)

3 Ebenezer Howard, Garden Cities of To-Morrow (London: Swan Sonnenschein, 1902)

$4 \quad$ Stanley Buder, Visionaries \& Planners: The Garden City Movement and the Modern Community (New York / Oxford: Oxford University Press), 1990, pp. 3-4

5 F. J. Osborn, "Preface," in: Howard, Garden Cities..., 1965, pp. 9-28; quotation: p. 26

$6 \quad$ Howard, Garden Cities..., 1965, pp. 45-47

$7 \quad$ On the Garden City Concept, read more:: Walter L. Creese, The Search for Environment - The Garden City: Before and After (New Haven / London: Yale University Press), 1966; William Petersen, "The ideological origins of Britain's new towns," Journal of American Institute of 
Planning (JAIP), Vol. 34, No. 3 (May, 1968), pp. 160-170; Stanley Buder, "Ebenezer Howard: the Genesis of a Town Planning Movement," JAIP, Vol. XXXV, No. 6 (Nov., 1969), pp. 390-398; A. E. J. Morris, "History of Urban Form - V, Origins of Garden City," Official Architecture and Planning (OAP), Vol. 34, No. 10 (Oct., 1971), pp. 779-781; A. E. J. Morris, "History of Urban Form - VI, From Garden Cities to New Towns," OAP, Vol. 34, No. 12 (Dec., 1971), pp. 922925; Peter Hall, Cities of Tomorrow: An Intellectual History of Urban Planning and Design in the Twentieth Century (Oxford / Cambridge, Mass.: Blackwell Publishers), 2002 [1988, 1996], pp. 87-141; Mervyn Miller, Letchworth, The First Garden City (Chichester: Phillimore \& Co. Ltd), 2002 [1989]; Buder, Visionaries \& Planners:..., 1990; Mervyn Miller, "Garden Cities and Suburbs: At Home and Abroad," Journal of Planning History, Vol. 1, No. 1 (Feb., 2002), pp. 6-28

According to: Др. Милослав Стојадиновић [Miloslav Stojadinović, PhD] “Од Сингидунума до модерног Београда" [From Singidunum to Modern Belgrade], in: Београд у прошлости и садашњости, Библиотека "Савремене општине" [Belgrade in the Past and in the Present Time, "Modern Municipality" Edition], No. 12 (Belgrade, 1927), pp. 31-58; quotation: p. 31

J.T.C. [Jefta Stefanović], “Регулација Београда," [The Regulation of Belgrade], Српски технички лист [Serbian Technical Paper], XXI, 49, 5 December, 1910, pp. 361-362

“Белешке, Литература," [Notes, Literature], Српски технички лист [Serbian Technical Paper], XXI, 52, 26 Dec, 1910, p. 400.

С. Б. [Stanojlo Babić], "Позоришни трг," [Theater Square], Српски технички лист [Serbian Technical Paper], XXV, 9, 2 March 1914, pp. 65-67, quotation: p. 66.

Д. Л. [Dimitrije T. Leko], “Мисли о могућности примене српског стила,” [Thoughts on possibility of application of Serbian style], Српски технички лист [Serbian Technical Paper], XIX, 25, 22 June 1908, pp. 233-234, quotation: pp. 233-234.This famous text was dedicated, actually, to a general question that preoccupied Serbian architects then, and that concerned, in the simplest words, the need of building in the Serbian national style, as well as defining that national style, and Leko, also, propagated the return to the local tradition.

Јан Дубови [Jan Dubový], “Вртарски град,” [Garden City], Tehnički list [Technical Paper], Vol. VII, No. 1, 1 January 1925, pp. 7-11; Vol. VII, No. 2, 15 January 1925, pp. 19-24; Vol. VII, No. 3, 15 February 1925 , pp. $42-46$

"According to the practical life and theory experience, during the mentioned year 'Garden City', founded by an Englishman Ebenezer Howard, encountered huge content. It is a city that gives us the land to cultivate and delivers us from big misfortune, sets the foundation to a healthy state and gives solution to social issues.” Јан Дубови [Jan Dubový], “Вртарски град,” [Garden City], Tehnički list [Technical Paper], Vol. VII, No. 1, 1 January 1925, pp. 7-11

Бранко Максимовић [Branko Maksimović], Проблеми урбанизма [Problems of Urbanism] (Belgrade: Geca Kon), 1932.

In the period between the World Wars (especially 1928-1935), we can find comparisons between garden cities and local old towns, as well as texts on similarity of the elemental principles of the residential architecture in them, in magazin Београдске опитинске новине [Belgrade Municipal Paper]. Slobodan Ž. Vidaković is author of the book: Слободан Ж. Видаковић [Slobodan Ž. Vidaković], Наши соиијални проблеми [Our Social Problems] (Belgrade: Geca Kon), 1932. Програм стечаја за израду генералног плана о уређењу и проширењу Београда [A Design Competition Program for the General Plan for Regulation and Expansion of Belgrade] (Општина града Београда / Municipality of Belgrade), 1921

Read more about the Professor's Colony: Драгана Ћоровић, “Примена концепта вртног града у Београду у периоду између два светска рата,” магистарска теза [Dragana Ćorović, "The Application of Garden City Concept in Belgrade between the World Wars" M.Sc. thesis], University of Belgrade - The Faculty of Architecture, 2008; pp. 161-178. It is, also published in the book: Мр Драгана Ћоровић [Dragana Ćorović, M.Sc.], Вртни град у Београду [A Garden City in Belgrade] (Belgrade: Zadužbina Andrejević), 2009, pp. 56-78 
Београда [On the Regulation of Belgrade, A Report of the Commission formed by the Board of Municipality of Belgrade] (Belgrade: Pravda), 1920

Извештај о генералном плану за град Београд, који је израдила комисија састављена решењем Одбора и Суда Општине Београдске од 29. маја 1922. године [A Report on General Plan for Belgrade, by the Commission formed by the Board and the Court of the Municipality of Belgrade, 29 May, 1922] (Општина града Београда / Municipality of Belgrade), 1923 Бранко Максимовић [Branko Maksimović], Идеје и стварност урбанизма Београда: 18301941 [Ideas and the Reality of the Urban Development of Belgrade] (Belgrade: Завод за заштиту споменика културе / Cultural Heritage Preservation Institute of Belgrade), 1983, quotation: p. 48 Михаило Радовановић [Mihailo Radovanović], Увод у урбанизам, Основни принципи и методе pada [Introduction to Town-Planning, Main Principals and Methods] (Belgrade, s.d.), 1933 Милутин Миланковић [Milutin Milanković], Успомене, доживљаји и сазнаға из година 1909 до 1944 [Memories, Experiences, Knowledges, 1909-1944] (Belgrade: Српска академија наука \& Научна књига / Serbian Academy of Science \& Scientific Book), 1952, pp. 206-208 Мирослава Димић [Miroslava Dimić], "Професорска колонија — изградња и њени оснивачи" [The Professor's Colony - Its Construction and its Founders], Годишњак града Београда [Yearbook of the City of Belgrade], XLV/XLVI (1998-99), pp. 71-82

Братислав Стојановић [Bratislav Stojanović], “Архитектура Београда од 1944 до 1954” [The Architecture of Belgrade, 1944-1954], Годишњак Музеја града Београда [Yearbook of the Museum of the City of Belgrade], I (1954), pp. 189-200, quotation: p. 189.

Those buildings were designed by the architect Vladeta Maksimović. Read more: Mate Baylon, "Stan u Beogradu" [A Dwelling in Belgrade] Arhitektura urbanizam [Architecture Urbanism], Vol. 14, No. 74-77, pp. 23-42

“[...] the outskirts [of the Professors' Colony] remained un-built and especially the part adjacent to Cvijićeva Street and the southern part of the Colony towards the Zdravka Čelara Street." Read more: Vesna Matičević, et al., Uslovi zaštite nepokretnih kulturnih dobara, dobara koja uživaju prethodnu zaštitu ambijentalnih vrednosti za potrebe elaborata: Detaljni urbanistički plan blokova između ulica 29. novembra, Mitropolita Petra i Čarli Čaplina [Terms of Protecting Immovable Cultural Goods, Goods which Enjoy the Protection of Previous Values for the Environmental Study: Detailed Regulation Plan of Blocks Between: 29. novembar, Mitropolita Petra and Čarli Čaplina Streets] (Belgrade: Zavod za zaštitu spomenika kulture grada Beograda / Cultural Heritage Preservation Institute of Belgrade) 1992, Signature: Ku-470. The author of texts on Professor's Colony in this project report is Zoran Manević, PhD.

\footnotetext{
IMAGE CREDITS

Fig. 1 Diagrams 1 and 3, E. Howard, Garden Cities of To-Morrow, 1965, pp. 46, 53

Fig. 2 Dwelling Quarters, Letchworth, 2007 (author's photography)

Fig. 3 A Design Competition Program for the General Plan for Regulation and Expansion of Belgrade, Municipality of Belgrade, 1921, cover

Fig. 4 Belgrade, 1921, Terrain of the future Professor's Colony, the Museum of the City of Belgrade, Ur. 3859

Fig. 5 Belgrade, 1930, the Professor's Colony, the Museum of the City of Belgrade, Ur. 4575

Fig. 6 The Professor's Colony, construction, Summer 1926, from Mr. Miloš Jurišić's collection; the photograph is published in newspaper Politika, in September 1926.

Fig. 7 The Professor's Colony, construction, c. 1926-27, from Mr. Miloš Jurišić's collection

Fig. 8 The Professor's Colony, c. 1930, from Mr. Miloš Jurišić's collection

Fig. 9 The Worker's Pavilions, c. 1946-47, from Mr. Miloš Jurišić's collection
} 